\title{
Ectopic pinealoma : an unusual clinical presentation and a histochemical comparison with a seminoma of the testis
}

\author{
J. M. BEELEY, J. J. DALY, W. R. TIMPERLEY, AND J. WARNER \\ From the Departments of Medicine and Neuropathology, The United Sheffield Hospitals, Sheffield
}

SUMMARY A patient with ectopic pinealoma first presented with apparent anorexia nervosa and hypernatraemic coma. A history of diabetes insipidus two months previously was not known on $\overrightarrow{0}$ admission to hospital. The diabetes insipidus was unmasked by the administration of steroids. $\overrightarrow{.}$ Neuroendocrinal and neuropathological aspects of the case are discussed with reference to the $\vec{\sigma}_{\Omega}$ march of symptoms due to the growth of the tumour. Histochemical evidence is presented supporting the similarity between ectopic pinealoma and seminoma which suggests that they may more properly? be referred to as atypical teratomas.

The first case of ectopic pinealoma was described by Stark in 1928; the patient exhibited diabetes insipidus, visual disturbance, and anterior pituitary insufficiency, which have since become recognized as a typical neuroendocrine triad associated with such a tumour. The initial symptom is usually diabetes insipidus and of the cases reviewed by Rubin and Kramer (1965) and in subsequent case reports (Beaufils, Chapman, and Nedey, 1968; Ghatak, Hirano, and Zimmerman, 1969; Vejjajiva and Sitprija, 1969; Schrub, Dubnisson, Hellemand, and Leroy, 1970; Kageyama, 1971; Sohn and Pittman, 1971) overt diabetes insipidus was present in 37 of the 41 patients described. Vejjajiva and Sitprija (1969) were the first to describe ectopic pinealoma with hypernatraemia in the absence of diabetes insipidus. Other uncommon features described as a result of hypothalamic involvement are disturbance of temperature regulation, hyperphagia, and anorexia.

This paper describes a patient with a diagnosis of anorexia nervosa who presented in hypernatraemic coma and in whom diabetes insipidus was unmasked by administration of steroids. At necropsy she was shown to have an ectopic pinealoma.

The derivation of such tumours has aroused considerable interest. They have been thought by various authors to be closely related to tre seminoma of the testis and to dysgerminoma of the ovary. Hence, they have been called geminomas and atypical teratomas. In view of tes? fact that a fresh specimen of tumour becanie음 available from a second case, it was felt that, comparing a variety of histochemical stains on the ectopic pinealoma, a seminoma of the testis, and the normal pineal gland, some evidence might be found to support either a pineal or germinomatous origin for this tumour.

\section{CASE REPORT}

In September 1971 a 22 year old single girl, who 을 worked as a children's nanny, was admitted to $\vec{P}$ hospital semi-comatose. The history available on admission was that in her early teens when $168 \mathrm{~cm}$ ( $5 \mathrm{ft} 6 \mathrm{in}$.) tall and only $50.4 \mathrm{~kg}(8 \mathrm{st})$ in weight, she considered herself overweight and went on a strict:diet. Menarche occurred normally at 14 years of age 3 . but menses ceased in August 1970. In September 1971 she became severely anorectic with resulting weight loss after she learned that her father had an inoperable carcinoma of the bronchus (Fig. 1). A diagnosis of anorexia nervosa was made at psychi- $-\frac{7}{0}$ atric consultation and treatment with tranquillizers and cyproheptadine resulted in improved appetite $N$ and slight weight gain. For one week before admission she complained of headaches and dizziness, and유 progressively became drowsy. 


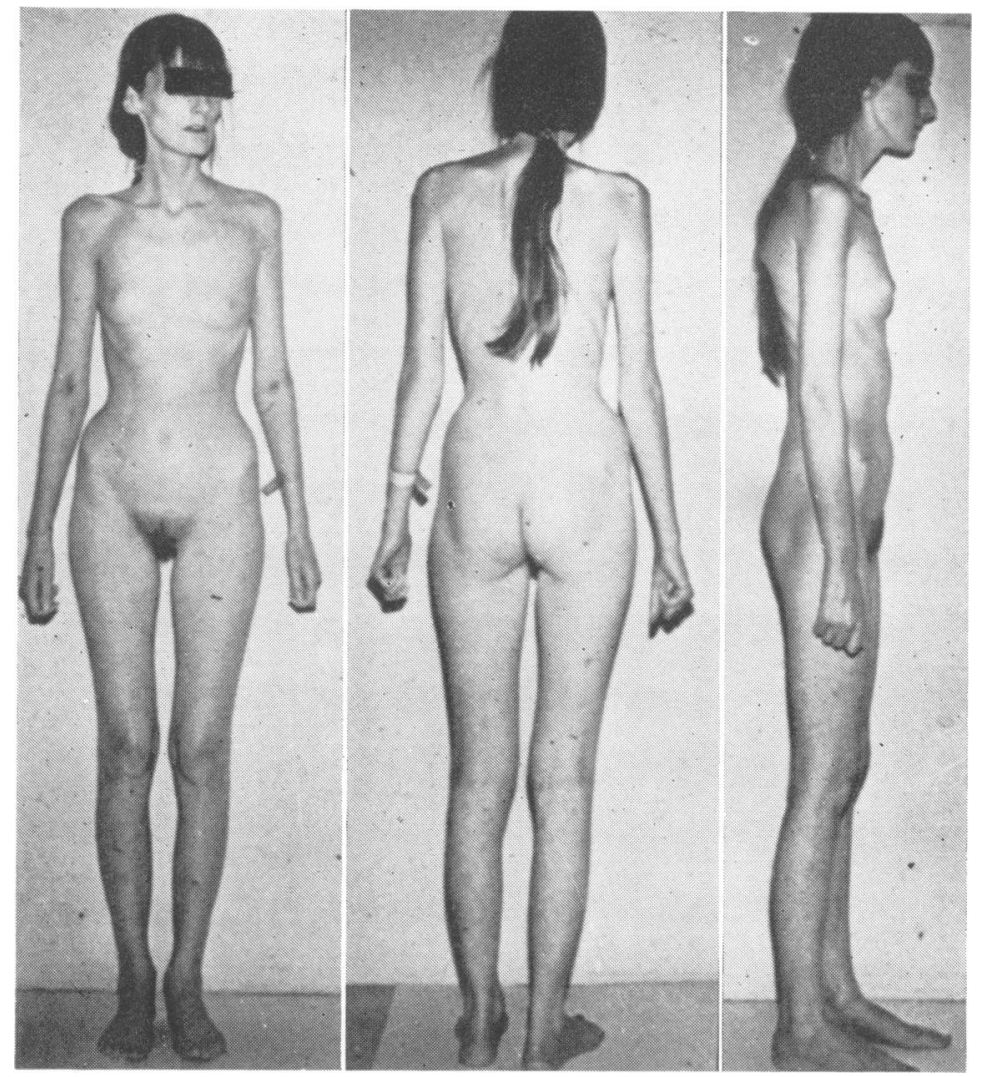

FIG. 1. Photograph of the patient showing the severe state of anorexia.

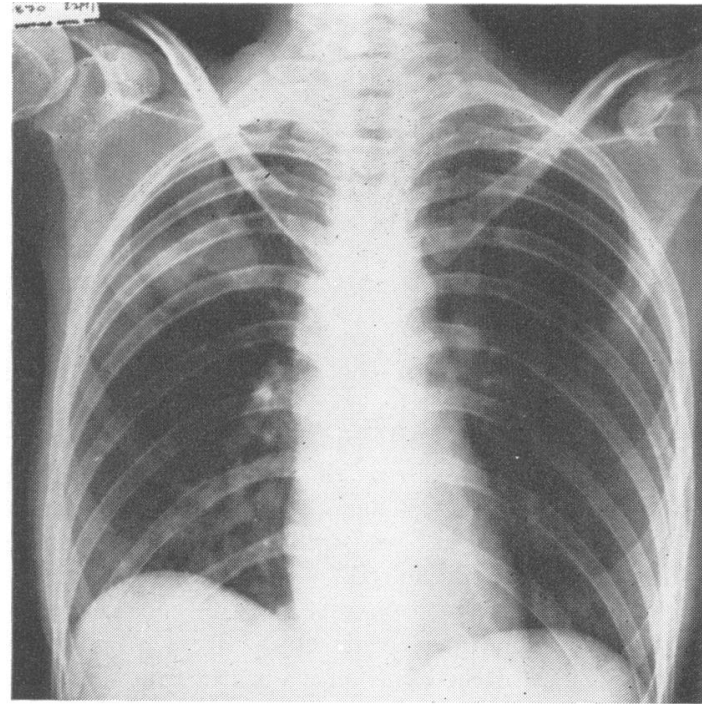

FIG. 2. Radiograph of the chest showing soft patchy opacities at the apex of the right lung.
EXAMINATION On admission she was semiconscious, emaciated, dehydrated, and pyrexial $\left(38^{\circ} \mathrm{C}\right)$. The pulse rate was $100 /$ minute and the blood pressure $95 / 60 \mathrm{mmHg}$. Her skin was pale and waxy; pubic and axillary hair was scanty. There was slight neck stiffness but no localizing neurological signs.

inVestigations Preliminary investigations revealed anaemia, hypernatraemic dehydration, an apparent lymphocytosis in the cerebrospinal fluid (CSF) and soft patchy opacities at the apex of the right lung on the radiograph of the chest (Fig. 2).

PRELIMINARY LABORATORY RESULTS Initial investigation showed: haemoglobin, $72 \%$ (iron deficient on film); leucocyte count, $10,000 / \mathrm{cmm}$ (normal differential); platelets 70,000/cmm; ESR $90 \mathrm{~mm} / \mathrm{hr}$ (Westergren); serum sodium $185 \mathrm{mEq} / \mathrm{l}$; ; serum potassium $3.1 \mathrm{mEq} / \mathrm{l}$; ; serum bicarbonate $27 \mathrm{mEq} / \mathrm{l}$; ; blood urea $66 \mathrm{mg} / 100 \mathrm{ml}$., and blood sugar $65 \mathrm{mg} / 100 \mathrm{ml}$

Examination of a mid-stream specimen of urine showed a specific gravity of 1.010 , a trace of albumin, no sugar, a positive test for ketones and no organisms. At lumbar puncture the cerebrospinal 


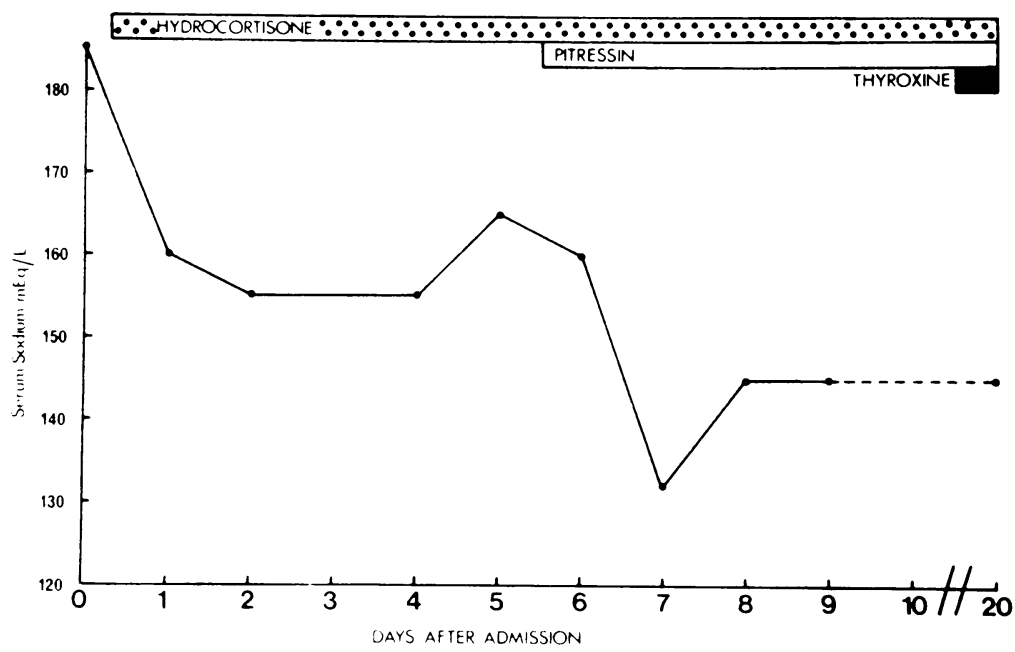

FIG. 3. Variation of serum sodium in relationship to treatment given.

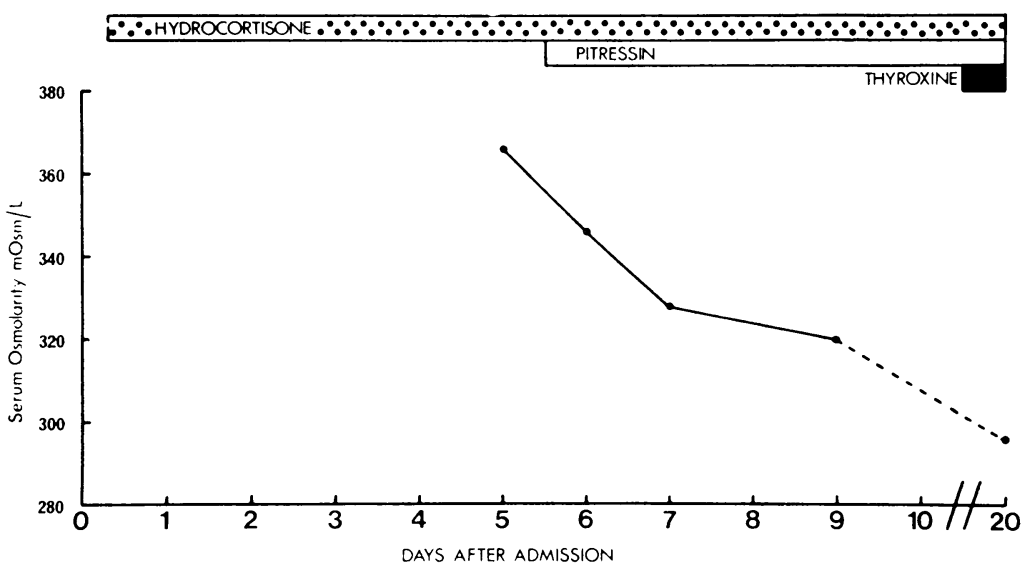

FIG. 4. Variation in serum osmolality in relationship t安 treatment given.

fluid showed a pressure of $150 \mathrm{~mm}$ water, white cell count $38 / \mathrm{cmm}(95 \%$ lymphocytes, $5 \%$ polymorphs), red cell count $7 / \mathrm{cmm}$, protein $70 \mathrm{mg} / 100 \mathrm{ml}$., sugar $55 \mathrm{mg} / 100 \mathrm{ml}$., and a negative Lange curve. Stains for bacteria including acid-fast bacilli were negative.

In view of the hypernatraemia, an intravenous infusion of $5 \%$ dextrose was immediately started and intravenous hydrocortisone was given as supportive therapy. Opacities in a radiograph of chest and the cells in the CSF suggested a diagnosis of tuberculosis and, therefore, streptomycin, isoniazid, and rifampicin were administered whilst further investiga-. tions were in progress. On this therapy, including continued hydrocortisone $100 \mathrm{mg}$ daily, there was only a marginal improvement in the electrolyte and clinical state. Though the volume of intravenous fluid was progressively increased to 61 ./day, the urine output persistently outstripped input.

It now became clear that she had developed diabetes insipidus and her clinical and biochemical 3 state began to improve only when subcutaneouso pitressin was administered.

Further investigations revealed reduced gonado- $\frac{D}{2}$ trophin production and thyroid hypofunction. Radiographs of the skull showed a normal pituitaryo fossa; echogram showed a central $8 \mathrm{~mm}$ third ventricle; electroencephalography (EEG) showed N widespread generalized slow wave activity and $a_{\sigma}^{\omega}$ 


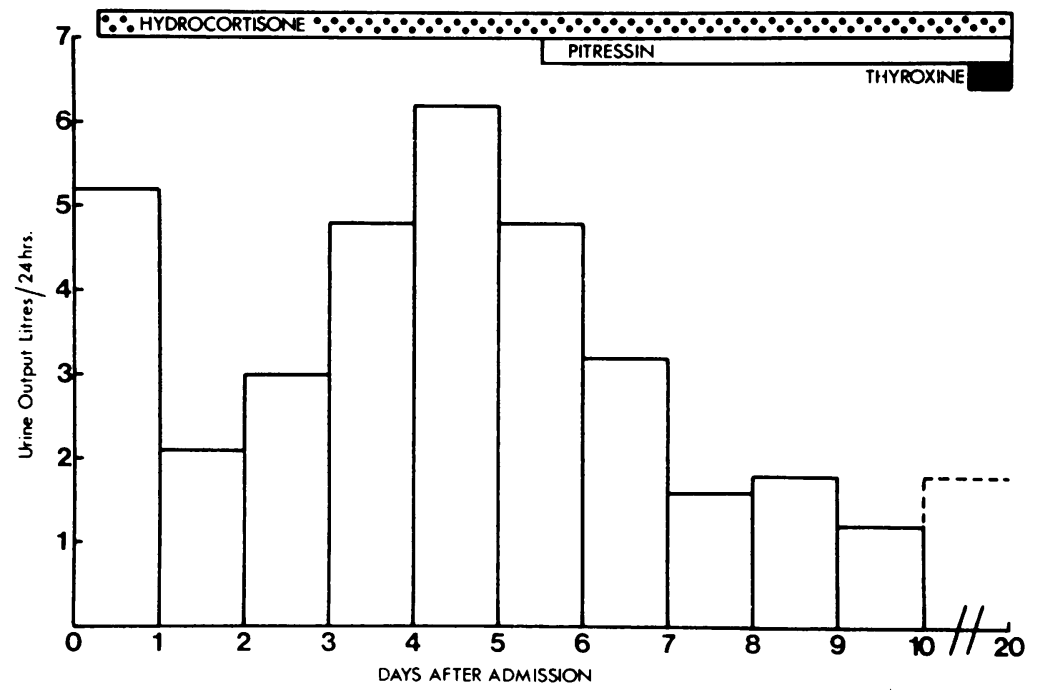

FIG. 5. Variation in urine output in relationship to treatment given.

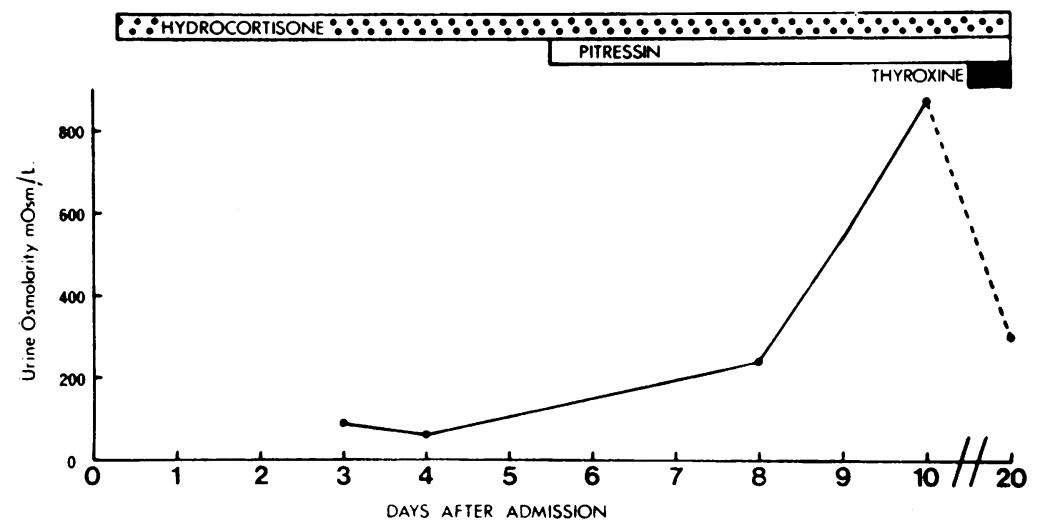

FIG. 6. Variation in urine osmolality in relationship to treatment given.

gammascan showed a high suprasellar uptake of isotope.

Other investigations at this stage showed a blood cholesterol of $125 \mathrm{mg} / 100 \mathrm{ml}$.; protein-bound iodine $2.7 \mu \mathrm{g} / 100 \mathrm{ml}$; and the $\mathrm{T}_{3}$ resin uptake test $21.4 \%$. Examination of the urine showed an excretion of $11.8 \mathrm{mg}$ of total oestrogens per 24 hours $(17.7 \mathrm{mg}=$ $100 \%) ; 2.0$ i.u. of follicular stimulating hormone per 24 hours and less than 10 i.u. of luteinizing hormone per 24 hours.

Within one week of admission the chest radiograph became clear and therefore antituberculous therapy was withdrawn. By this time she was fully 'conscious and able to give a history of one month's transient polydypsia and of polyuria two months before admission.

Steroids were now withdrawn and a short synacthen test revealed a low resting cortisol level with a normal response. The resting cortisol level at 9.00 a.m. was $5.3 \mu \mathrm{g} / 100 \mathrm{ml}$. After $1 \mathrm{mg}$ synacthen subcutaneously the cortisol level was $20 \mu \mathrm{g} / 100 \mathrm{ml}$. after 45 minutes and $23.2 \mu \mathrm{g} / 100 \mathrm{ml}$. after 60 minutes.

Steroids were then reintroduced and pitressin was withdrawn for a trial period during which time she developed a high urinary output with resulting hypernatraemia and dehydration. Despite high serum osmolalities she did not become thirsty at any 


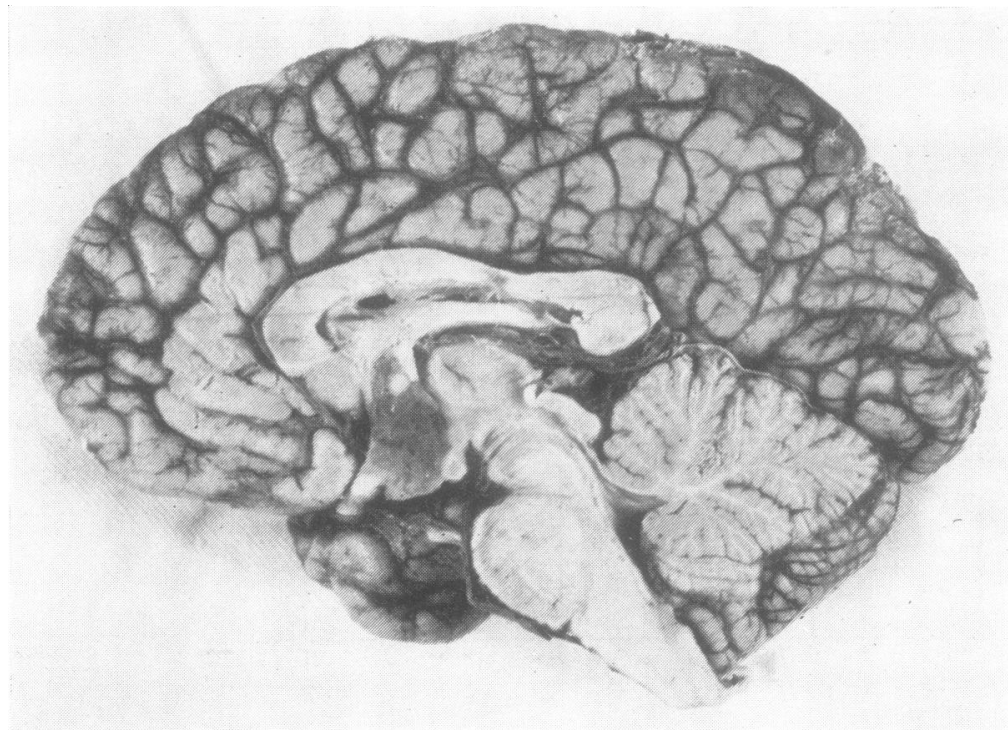

FIG. 7. Sagittal section of brain showing the tumour in the hypothalamus.

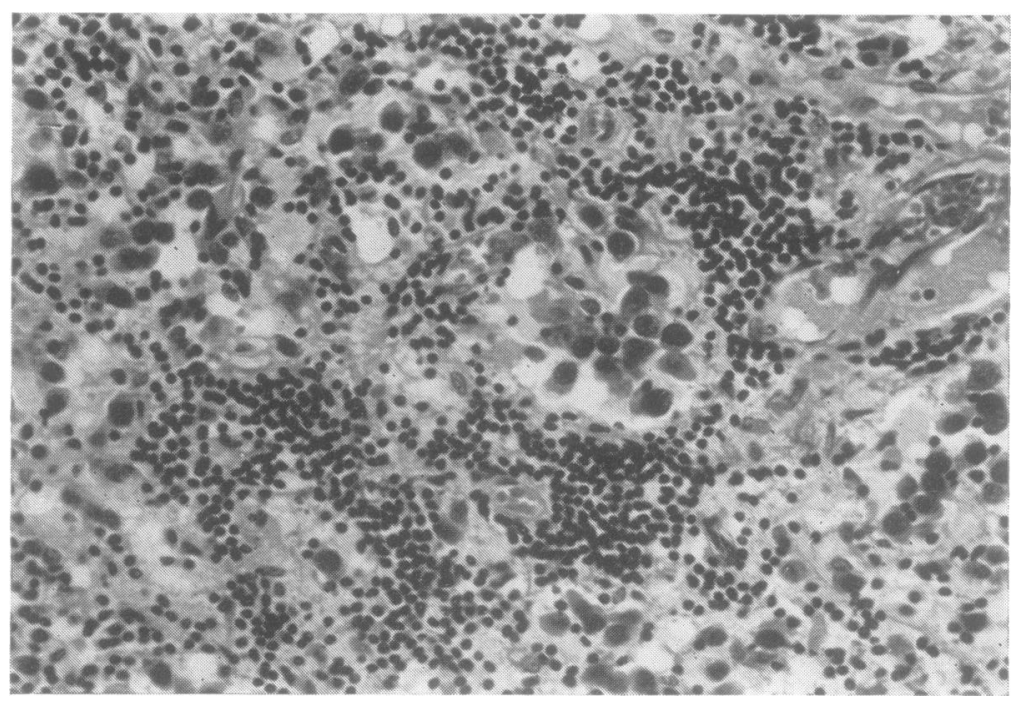

FIG. 8. Section of tumour showing two main cell types. Haematoxylin and eosin stain. $\times 535$.

stage. Pitressin was therefore recommenced and fluid balance was restored.

Subsequently, steroids were again withdrawn and she became oliguric ( $700 \mathrm{ml}$. urine/day) with a high urinary osmolality $80(\mathrm{mosm} / \mathrm{l}$.) and low serum osmolality (257 mosm/1.).

Figures 3 to 6 show the variations in serum sodium and osmolality and urine output and osmolality respectively in relationship to the treatment given.

At this stage a diagnosis of hypothalamic tumoun was assumed and full replacement therapy with steroids, pitressin, and thyroxin was commenced For a short period her general condition remained satisfactory with reasonable control of fluid and 
electrolyte balance, though she was persistently hypothermic and her optic discs appeared progressively paler.

Before any definitive treatment could be considered, she lapsed into coma without disturbance of fluid balance and developed extensor spasms of the arms and flexor spasms of the legs. She died without regaining consciousness.

POST MORTEM EXAMINATION The body was that of an emaciated girl aged 22 years. The relevant gross findings were confined to the brain where there was a partially cystic greyish mass of tumour in the hypothalamus extending from the mamillary bodies posteriorly to the optic chiasma anteriorly. It involved the lamina terminalis and the anterior and medial thalamus (Fig. 7). The lungs showed bronchopneumonia.

Histologically, the tumour was composed of two cell types, one cell being small and round and very similar to a lymphocyte; the other type was considerably larger, with round nuclei and prominant nucleoli (Fig. 8). Mitotic figures were easily found. The cysts noted macroscopically were full of pale eosinophilic colloid. No other tissue components were seen in sections taken at multiple levels. The tumour appeared to be actively infiltrating the cerebral tissues at its edges and there was a mild gliotic reaction around it. The picture was that of an 'ectopic pinealoma' (germinoma or atypical teratoma).

\section{CASE 2}

A fresh sample of tumour was provided from a necropsy on a woman aged 19 years with an ectopic pinealoma by Dr. P. G. Lynch, Department of Neuropathology, Manchester University. Histologically the tumour showed features similar to the previous case.

\section{METHODS}

A sample of fresh testicular seminoma was obtained from a surgical specimen. Three normal adult pineal glands were obtained from necropsies performed within 12 hours of death. Blocks from all three tissues were frozen onto chucks with liquid nitrogen and cryostat sections were cut at $10 \mu$. The following histochemical staining reactions were performed:

DeHYdRogenases The technique was that of Pearse (1960) using the following substrates: sodium Lglutamate, sodium DL- $\beta$-hydroxybutyrate, glucose-6phosphate disodium salt, 6-phosphogluconic acid barium salt, sodium DL- $\alpha$-glycerophosphate, sodium DL-isocitrate, sodium lactate, sodium succinate, and sodium malate. A fresh solution of $0 \cdot 1 \mathrm{M}$ triphosphopyridine nucleotide was used for the pentoseshunt enzymes, no coenzyme was used for succinic dehydrogenase, and $0.1 \mathrm{M}$ diphosphopyridine nucleotide was used for the rest. Sodium cyanide $(0 \cdot 1 \mathrm{M})$ was used as a respiratory inhibitor for all enzymes except the pentose-shunt enzymes where $0 \cdot 1 \mathrm{M}$ sodium azide was used instead.

Sections were incubated for 45 minutes at $37^{\circ} \mathrm{C}$.

DIAPHORASES Sections were incubated in a medium containing $0 \cdot 1 \mathrm{M}$ reduced diphosphopyridine nucleotide (DPNH) or reduced triphosphopyridine nucleotide (TPNH) and nitroblue-tetrazolium at $\mathrm{pH}$ $7 \cdot 4$ for 45 minutes.

CYTOCHROME OXIDASE The method of Burstone (1960) using p-aminodiphenylamine and 3-amino-9ethylcarbazole was used. Sections were incubated for one hour before chelation in cobaltous acetate.

ALKALINE PHOSPHATASE A naphthol AS-TR phosphate method was used (Burstone, 1958). The pH of the incubating medium was 8.9 and Red Violet L-B salt was used as coupling agent.

ACID PHOSPHATASE A similar method to that used for alkaline phosphatase was used except that the $\mathrm{pH}$ of the incubating medium was $\mathbf{5 \cdot 2}$.

NON-SPECIFIC ESTERASE The method was based on Gomori's modification of the technique of Nachlas and Seligman (1949) using $\alpha$-naphthyl acetate as substrate, and Fast Blue BB salt as coupling agent.

TABLE

ENZYMES FOUND IN DIFFERENT TISSUES EXAMINED

\begin{tabular}{|c|c|c|c|c|c|c|}
\hline \multirow[t]{2}{*}{ Enzyme } & \multicolumn{2}{|c|}{ Pinealoma } & \multicolumn{2}{|c|}{ Seminoma } & \multicolumn{2}{|c|}{ Pineal gland } \\
\hline & $\begin{array}{c}\text { Large } \\
\text { cells }\end{array}$ & $\begin{array}{c}\text { Small } \\
\text { cells }\end{array}$ & $\begin{array}{c}\text { Large } \\
\text { cells }\end{array}$ & $\begin{array}{c}\text { Small } \\
\text { cells }\end{array}$ & $\begin{array}{c}\text { Pineo- } \\
\text { cytes }\end{array}$ & Glia \\
\hline \multicolumn{7}{|l|}{ Dehydrogenases } \\
\hline 6-phospho-gluconic acid & + & + & + & + & + & + \\
\hline G-6-Phosphate & + & + & + & + & + & + \\
\hline$\alpha$-glycerophosphate & + & + & + & + & + & + \\
\hline Lactic acid & + & + & + & + & + & + \\
\hline Isocitric acid & + & + & + & + & + & + \\
\hline Succinic acid & + & + & + & + & + & + \\
\hline Malic acid & + & + & + & + & + & + \\
\hline Glutamic acid & + & + & + & + & + & + \\
\hline$\beta$-Hydroxy-butyric acid & + & + & + & + & + & + \\
\hline DPNH diaphorase & + & + & + & + & + & + \\
\hline TPNH diaphorase & + & + & + & + & + & + \\
\hline Cytochrome oxidase & + & + & + & + & + & + \\
\hline Acid phosphatase & + & + & + & + & + & + \\
\hline Esterase & + & + & + & + & + & + \\
\hline Leucine amino-peptidase & 0 & 0 & 0 & 0 & 0 & 0 \\
\hline Alkaline phosphatase & + & - & + & - & - & 一 \\
\hline
\end{tabular}




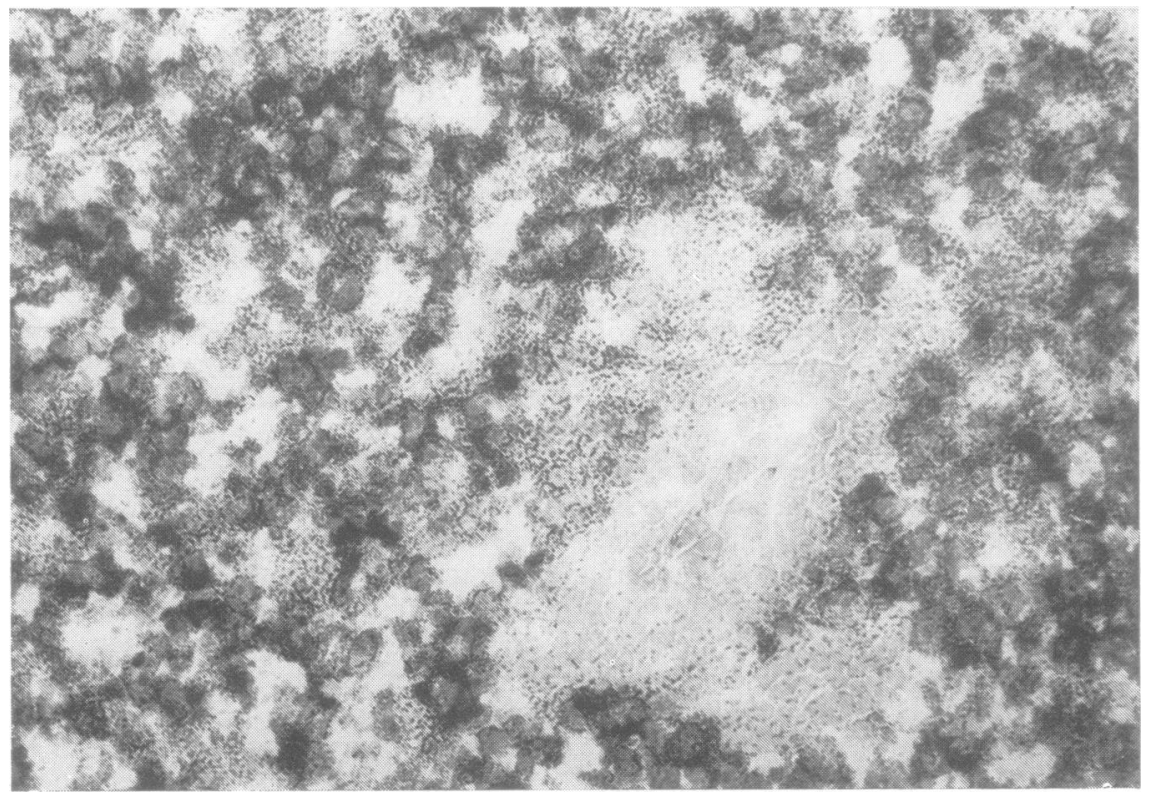

FIG. 9. Non-specific esterase stain on pinealoma showing strong activity in large cells and weak activity in small lymphocyte-like cells. $\times 540$.

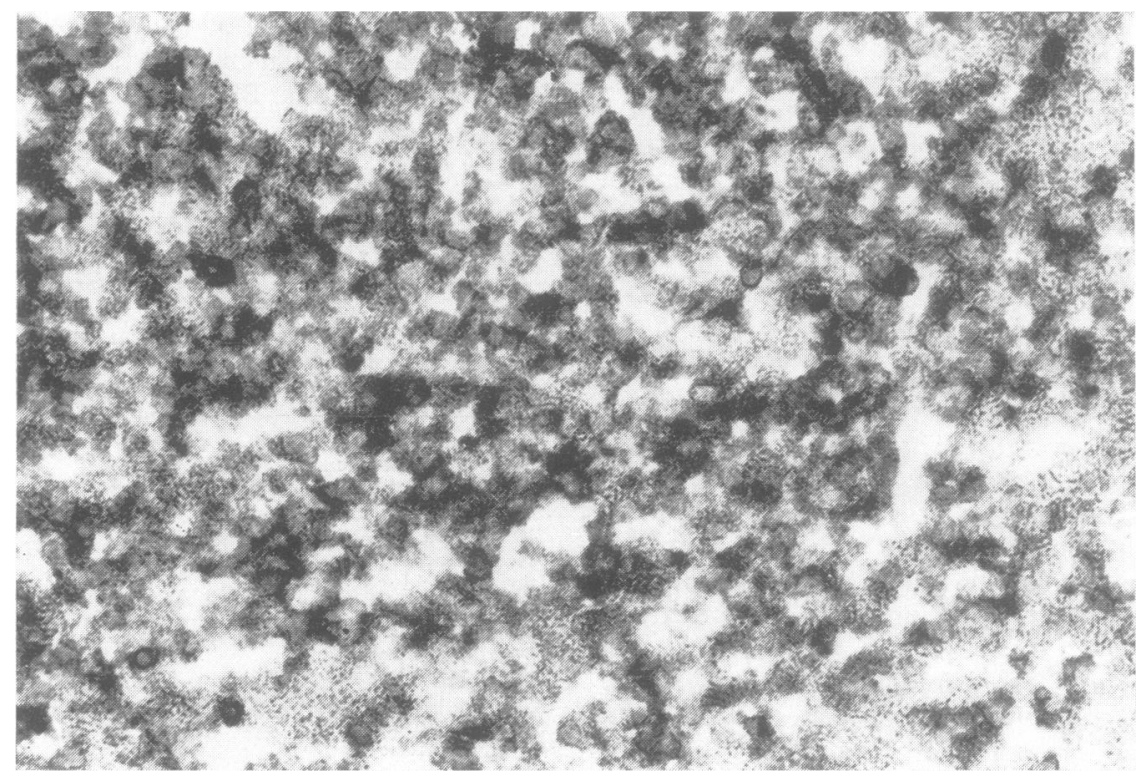

FIG. 10. Non-specific esterase stain on seminoma showing strong staining of large cells and weak staining of lymphocytes. $\times 540$. 


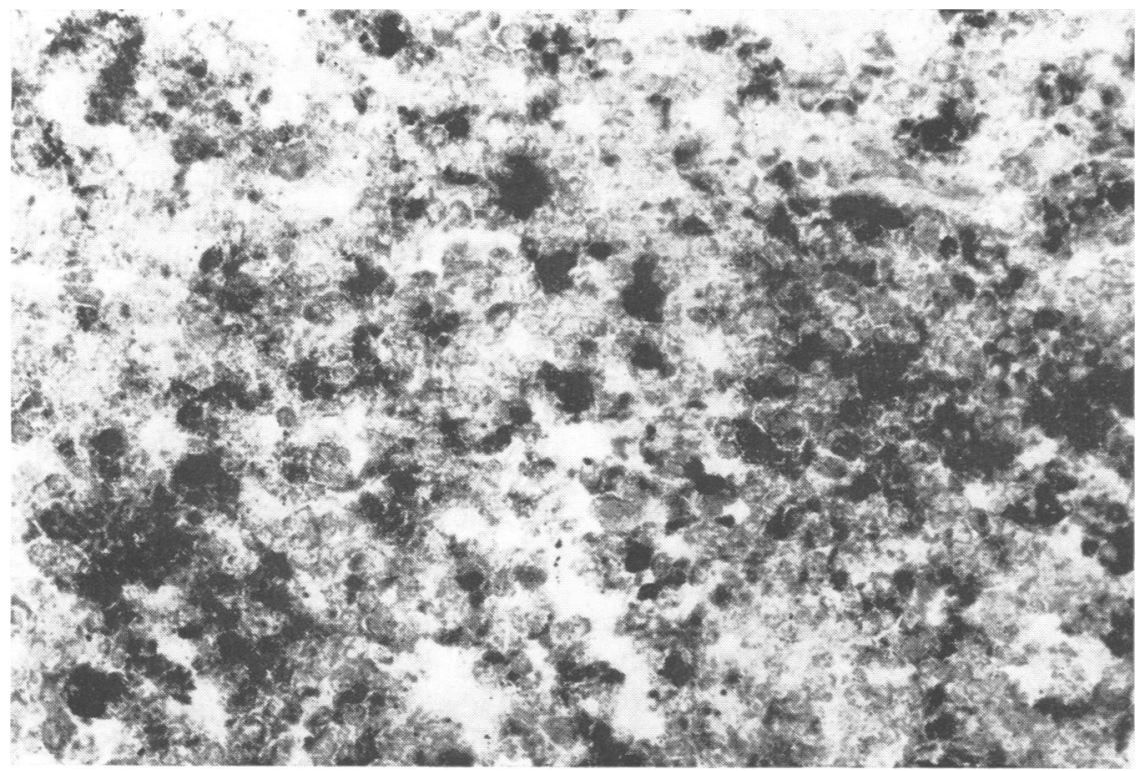

FIG. 11. Alkaline phosphatase stain on pinealoma showing strong staining of large cells and negative reaction in small cells. $\times 800$.

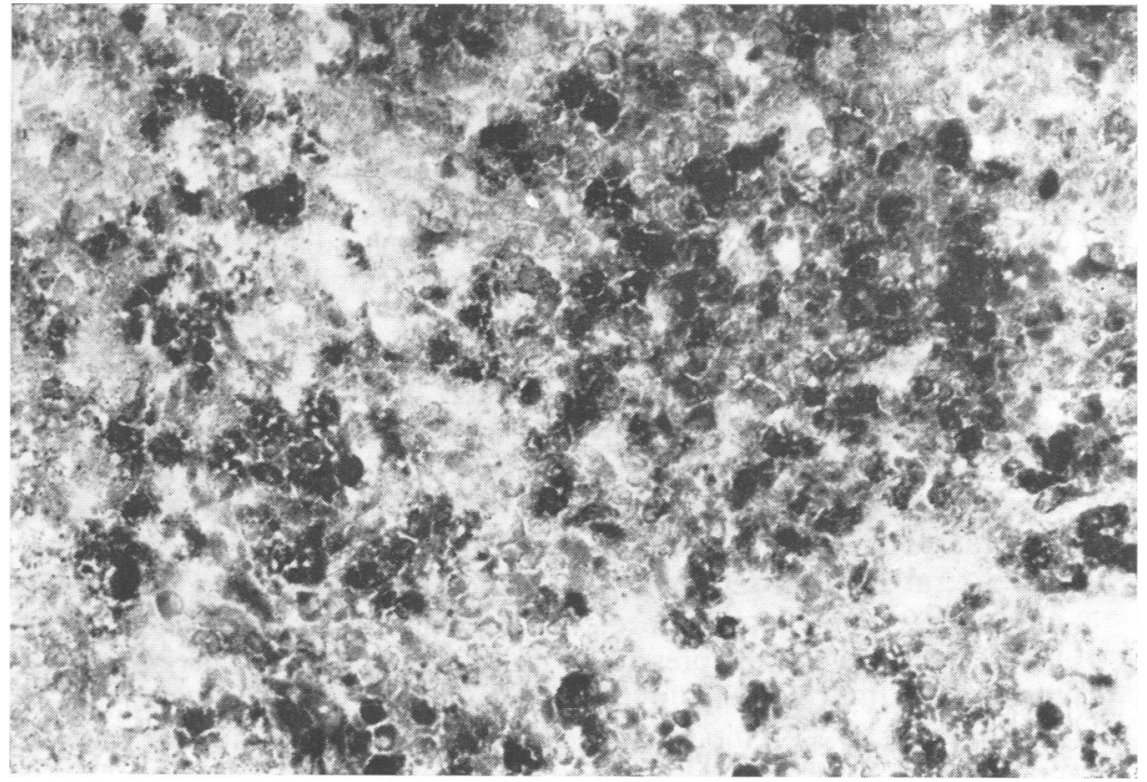

FIG. 12. Alkaline phosphatase stain on seminoma showing strong reaction in large cells and negative reaction in lymphocytes. $\times 540$. 
LEUCINE AMINOPEPTIDASE The method was that of Burstone and Folk (1956) using L-leucyl- $\beta$-naphthylamide as substrate. Sections were incubated for one hour at $\mathrm{pH} 7 \cdot 1$.

\section{RESULTS}

The Table shows the enzymes found in the various cell types. All enzymes investigated, with the exception of leucine aminopeptidase and alkaline phosphatase, were present in all cell types. The large cells of both the pinealoma and seminoma and the pineocytes showed stronger activity than the small round cells and glia (Figs 9 and 10). No cells showed leucine aminopeptidase activity.

The most striking and significant feature was the presence of strong alkaline phosphatase activity in the large cells of both the pinealoma and the seminoma (Figs 11 and 12). No activity was seen in pineocytes.

\section{DISCUSSION}

There has been a considerable amount of controversy as to the nature of the 'ectopic pinealoma'. They have been thought by some (Russell, 1954, Løken, 1957, Simson, Lampe, and Abell, 1968) to be closely related to the germinomas of the pineal gland, the seminoma of the testis, and the dysgerminoma of the ovary.

In an electron microscopical study Ramsey (1965) stated that this type of tumour shows no striking resemblance to epithelial cells, ependymal cells, or parenchymal cells of the pineal gland. Brihaye and Parmentier (1955) also felt that the lack of affinity for silver of the large cells was against their being derived from pineal parenchymal cells. We are unaware of any previous histochemical comparison between this type of tumour and a seminoma of the testis.

The histochemical finding of a virtually identical pattern in the ectopic pinealoma and the seminoma provides some further evidence that these two tumours are, in fact, closely related and that the term atypical teratoma is probably more appropriate than ectopic pinealoma. The most striking feature was the presence of strong alkaline phosphatase activity in the large cells of both tumour types. This enzyme was not seem in pineocytes of the normal pineal gland. The similarities between the other enzymes studied could occur by chance as they are nearly all possessed to a certain degree by most cell types. Large cells would probably be expected to show a higher activity in view of the greater amount of cytoplasm. Alkaline phospha- 0 tase, however, is an uncommon enzyme and is related in most cases to specific function, usually? to the transport of substances across membranes - that is, in capillaries, choroid plexus, arachnoid. granulations, biliary epithelium, small intestinal $\overrightarrow{\overrightarrow{\vec{s}}}$ epithelium, and the proximal renal convolutedo tubule. It is unlikely that the finding of itso activity in two histologically similar cells would $\frac{\bar{s}}{\square}$ be found by chance alone, certainly in view of the fact that no similar cell is seen in the normates pineal gland.

On the clinical side the first case showedseveral features of additional interest. It pre-w sented with a symptom complex which was confidently diagnosed and successfully treateç as anorexia nervosa. The patient was a youngw female with a higher than average IQ who hajor become involved in the pursuit of thinnesso (Bruch, 1965; British Medical Journal, 196\$) While Lewin, Mattingly, and Millis (1972) hage? described a case of anorexia nervosa due towa well differentiated astrocytoma, they were unable to explain the anorexia on anatomical ground as the tumour, unlike our case of ectopic pineg oma, was not involving the lateral hypothalamis where animal experiments have located the feeding centre (Anand and Brobeck, 1951).

The subsequent hospital presentation of ous case in hypernatraemic coma raised varioug possibilities; these included hyperosmolar dia betic coma, diabetes insipidus, nephrogeni diabetes insipidus, intracranial disease, sals poisoning, or gastrointestinal fluid loss. The absence of any recent polyuria or polydypsi seemed to exclude a diagnosis of diabetes insipidus and other possibilities were not subs stantiated. It would seem likely that the hyperio natraemic dehydration was explained by the development of hypodypsia due to destruction of the thirst centre in the anterior hypothalamus. This is a rare occurrence that has previouslo been described as occurring after subarachnoid haemorrhage (Jenkins, 1972).

The supportive administration of steroids when our patient was comatose resulted in gross polyuria due to unmasking of diabetes insipiduks It is known that cortisol is necessary for the 
excretion of a water load and that integrity of adenophyseal function is necessary for the polyuria of diabetes insipidus. In our case, the anterior pituitary gland was shown to be histologically normal and we believe that its function was impaired as a result of destruction of the median eminence of the hypothalamus where releasing hormones, including corticotrophin releasing factor, are produced. As the posterior pituitary gland was also intact, the diabetes insipidus was presumably due to damage occurring at some level up to, or including, the supraoptic nucleus. It is not unusual to encounter transient symptoms of diabetes insipidus, as in our patient, when posterior pituitary function is first lost and cortisol production is subsequently impaired. Furthermore, corticosteroid administration in this situation will unmask diabetes insipidus (Kageyama, 1971).

There are a few reports of successful treatment of ectopic pinealoma by radiotherapy (Horrax and Wyatt, 1947; Troland and Brown, 1948; Rubin and Kramer, 1965; Kageyama, 1971). It is important, therefore, to recognize the possibility of ectopic pinealoma presenting in the manner of our patient.

We would like to thank the Department of Medical Illustration at the United Sheffield Hospitals for preparing the graphs and Mr. K. Horton, chief technician in the Department of Neuropathology for his technical help.

\section{REFERENCES}

Anand, B. K., and Brobeck, J. R. (1951). Localization of 'feeding center' in hypothalamus of rat. Proceedings of the Society for Experimental Biology and Medicine, 77, 323324.

Beaufils, F., Chapman, A., and Nedey, R. (1968). Un cas de pinéalome ectopique. Anesthésie, Analgésie, Réanimation, 25, 429-439.

Brihaye, J., and Parmentier, R. (1955). Pinéalome ectopique dans la région chiasmatique. Semaine des Hôpitaux, Archives d'Anatomie Pathologique, 31, A.170-A.174.

Bruch, H. (1965). Anorexia nervosa and its differential diagnosis. Journal of Nervous and Mental Disease, 141, $555-566$.
Burstone, M. S. (1958). Histochemical comparison of naphthol AS-phosphates for the demonstration of phosphatases. Journal of the National Cancer Institute, 20, 601-615.

Burstone, M. S. (1960). Histochemical demonstration of cytochrome oxidase with new amine reagents. Journal of Histochemistry and Cytochemistry, 8, 63-70.

Burstone, M. S., and Folk, J. E. (1956). Histochemical demonstration of aminopeptidase. Journal of Histochemistry and Cytochemistry, 4, 217-226.

Ghatak, N. R., Hirano, A., and Zimmerman, H. M. (1969). Intrasellar germinomas: A form of ectopic pinealoma. Journal of Neurosurgery, 31, 670-675.

Horrax, G., and Wyatt, J. P. (1947). Ectopic pinealomas in the chiasmal region: report of three cases. Journal of Neurosurgery, 4, 309-326.

Jenkins, J. S. (1972). The hypothalamus. British Medical Journal, 2, 99-102.

Kageyama, N. (1971). Ectopic pinealoma in the region of the optic chiasm. Report of five cases. Journal of Neurosurgery, 35, 755-759.

British Medical Journal (1969). Anorexia nervosa (leading article). British Medical Journal, 1, 529-530.

Lewin, K., Mattingly, D., and Millis, R. R. (1972). Anorexia nervosa associated with hypothalamic tumour. British Medical Journal, 2, 629-630.

Loken, A. C. (1957). On the relation of atypical pinealomas to teratoid tumours. Acta Pathologica et Microbiologica Scandinavica, 40, 417-424.

Nachlas, M. M., and Seligman, A. M. (1949). The histochemical demonstration of esterase. Journal of the National Cancer Institute, 9, 415-425.

Pearse, A. G. E. (1960). Histochemistry: Theoretical and Applied. 2nd edn. Churchill: London.

Ramsey, H. J. (1965). Ultrastructure of a pineal tumour. Cancer, 18, 1014-1025.

Rubin, P., and Kramer, S. (1965). Ectopic pinealoma: a radiocurable neuroendocrinologic entity. Radiology, 85, 512-523.

Russell, D. S. (1954). 'Ectopic pinealoma': its kinship to atypical teratoma of the pineal gland. Report of case. Journal of Pathology and Bacteriology, 68, 125-129.

Schrub, J.-Cl., Dubnisson, M., Hellemand, B., and Leroy, J.-Cl. (1970). L'hypernatrémie neurogène. Semaine des Hopitaux de Paris, 46, 2084-2089.

Simson, L. R., Lampe, I., and Abell, M. R. (1968). Suprasellar germinomas. Cancer, 22, 533-544.

Sohn, A. P., and Pittman, J. G. (1971). Multiple hypothalamic disorders produced by a suprasellar germinoma. Rocky Mountain Medical Journal, 68, 23-27.

Stark, H. (1928). Tumor der glandula pinealis und des Hypophysisgebietes. Zentralblau fiir die gesamte Neurologie und Psychiatrie, 48, 72-73.

Troland, C. E., and Brown, C. A. (1948). Precocious puberty of intracranial origin. Journal of Neurosurgery, 5, 541-555.

Vejjajiva, A., and Sitprija, V. (1969). Chronic sustained hypernatremia and hypovolemia in hypothalamic tumour. A physiologic study. Neurology (Minneap.), 19, 161-166. 